\title{
Systemic Modulation of Gene Expression in Tomato by Trichoderma hamatum 382
}

\author{
G. Alfano, M. L. Lewis Ivey, C. Cakir, J. I. B. Bos, S. A. Miller, L. V. Madden, S. Kamoun, and H. A. J. Hoitink
}

First author: Department of Agri-Food Environmental and Microbiological Science and Technology, University of Molise, Campobasso, Italy; second, fourth, fifth, sixth, seventh, and eighth authors: Ohio Agricultural Research and Development Center, Ohio State University, Department of Plant Pathology, Wooster 44691; and third author: United States Department of Agriculture-Agricultural Research Service, Crop Production and Pest Control Unit, Department of Agronomy, Purdue University, Lilly Hall of Sciences, 915 West State Street, West Lafayette, IN 47907-2054.

Accepted for publication 22 November 2006.

\begin{abstract}
Alfano, G., Lewis Ivey, M. L., Cakir, C., Bos, J. I. B., Miller, S. A., Madden, L. V., Kamoun, S., and Hoitink, H. A J. 2007. Systemic modulation of gene expression in tomato by Trichoderma hamatum 382. Phytopathology 97:429-437.

A light sphagnum peat mix inoculated with Trichoderma hamatum 382 consistently provided a significant $(P=0.05)$ degree of protection against bacterial spot of tomato and its pathogen Xanthomonas euvesicatoria $110 \mathrm{c}$ compared with the control peat mix, even though this biocontrol agent did not colonize aboveground plant parts. To gain insight into the

entially expressed across the replicated treatments, and 41 of these genes could be assigned to at least one of seven functional categories. T. hamatum 382-induced genes have functions associated with biotic or abiotic stress, as well as RNA, DNA, and protein metabolism. Four extensin and extensin-like proteins were induced. However, besides pathogenesis-related protein 5, the main markers of systemic acquired resistance were not significantly induced. This work showed that T. hamatum 382 actively induces systemic changes in plant physiology and disease resistance through systemic modulation of the expression of stress and metabolism genes.
\end{abstract} mechanism by which T. hamatum 382 induced resistance in tomato, highdensity oligonucleotide microarrays were used to determine its effect on the expression pattern of 15,925 genes in leaves just before they were inoculated with the pathogen. T. hamatum 382 consistently modulated the expression of genes in tomato leaves. We identified 45 genes to be differ-
Additional keywords: extensins, ISR, Lycopersicon esculentum, mechanism of induced resistance, microarray analysis, Solanum lycopersicum, $X$. campestris pv. vesicatoria.
Trichoderma spp. can reduce the severity of plant diseases through several different mechanisms $(11,13,14,17,21,42)$. Some strains inhibit or eradicate propagules of plant pathogens in the soil or on roots of plants through antagonism $(20,38)$ and mycoparasitism (7). Several Trichoderma strains that provide these effects and colonize roots also may impact the severity of foliar diseases of plants (14). Examples of strains for which such systemic effects have been described include T. asperellum T203 (43), T. hamatum 382 (24), T. harzianum T39 (10), T. harzianum T22 (15), and $T$. virens (22). A single Trichoderma strain may induce such systemic effects in several different plant species against several types of diseases (14). For example, potting mixes inoculated with $T$. hamatum 382 can suppress the severity of bacterial leaf spots of Arabidopsis and several vegetable crops $(3,24,47)$, Botrytis blight on begonia (19), Phytophthora blight of cucumber (23), and Phytophthora blights and Botryosphaeria dieback on ericaceous plants (17). Protection provided by this systemic effect against several diseases is generally mild, but control of stress diseases such as Botryosphaeria dieback can be highly effective (17).

Systemic disease control provided by root-colonizing Trichoderma strains involves complex interactions between the host plant, the pathogen, the biocontrol agent, and several different environmental factors $(14,17)$. Some strains enhance plant growth and facilitate uptake of essential plant nutrients which, apart from

Corresponding author: H. A. J. Hoitink; E-mail address: hoitink.1 @ osu.edu

doi:10.1094/PHYTO-97-4-0429

(c) 2007 The American Phytopathological Society induced resistance, may indirectly contribute to systemic disease control $(13,46)$. T. harzianum T22, for example, has the greatest effect on plant growth and disease control under stress conditions (13). Soil quality factors such as the decomposition level of organic matter also may affect the degree of systemic control provided by Trichoderma spp. $(16,17,47)$. A similar effect of soil organic matter on systemic disease control has been described for the biocontrol agent Pythium oligandrum against Fusarium crown rot of tomato (30). Therefore, any analysis of the mechanisms by which Trichoderma strains provide systemic effects in plants against diseases requires careful control of experimental protocols.

Systemic induction of plant defenses currently is viewed as the central mechanism by which Trichoderma spp. diminish foliar diseases $(14,42)$. According to this model, specific Trichoderma strains establish superficial colonization of root tissues. Thus, although the fungus may fail to invade the root beyond a few cell layers below the epidermis (43), colonization is long lasting and results in the systemic enhancement of resistance through the release of defense elicitors. For example, Sm1, a small proteinaceous elicitor secreted by $T$. virens, was isolated recently (11).

The nature of systemic resistance activated by Trichoderma spp. remains unclear. Although significant activation of pathogenesis-related proteins and other defense-related molecules has been noted in roots and upper leaves of colonized plants $(2,14$, $39,44,45$ ), salicylic acid (SA) is not involved, suggesting a pathway distinct from systemic acquired resistance (SAR) (34, 39). On the other hand, indirect evidence suggests that jasmonic acid (JA) plays a role in systemic resistance induced in cucumber by T. asperellum T203 (39). Even so, a recent study with a similar Trichoderma strain, T. asperellum T-34, failed to detect increased 
JA levels in cucumber plants inoculated with this biocontrol agent (34). The systemic responses induced by Trichoderma spp. seem to resemble the type of induced systemic resistance (ISR) activated by rhizobacteria in plants $(9,14,31)$.

Even though there is a significant body of literature describing the potentiation and induced activation of resistance to pathogens by Trichoderma spp., global analyses of the systemic alterations of plant gene expression induced by these fungi have not been described to our knowledge. In this study, we established a biocontrol assay using tomato with T. hamatum 382 as a treatment in a potting mix followed by secondary inoculation of the foliage with the bacterial spot pathogen Xanthomonas euvesicatoria (syn. $X$. campestris pv. vesicatoria) 110c. Bacterial spot was chosen as the test pathogen because preliminary experiments revealed that this disease of tomato can provide quantitative information on systemic resistance induced by T. hamatum 382 in plants (3). In order for the protective effect induced by T. hamatum 382 in tomato to be due to systemic activity, it is imperative that the inducer remain spatially separated from the pathogen (X. euvesicatoria 110c) in the host plant (31). Thus, the first objective was to establish spatial separation between T. hamatum 382 and $X$. euvesicatoria $110 \mathrm{c}$ in tomato plants in this work. The second objective was to profile the impact of T. hamatum 382 on the expression of 15,925 tomato genes during the time period that plants were inoculated with the pathogen through the use of highdensity oligonucleotide microarrays. Finally, the third objective was to functionally annotate the genes differentially expressed between the control and $T$. hamatum 382 treatments to gain insight into the mechanism of induced resistance.

\section{MATERIALS AND METHODS}

Potting mixes and inoculum of $T$. hamatum 382. A potting mix consisting of a mixture of light peat and perlite was prepared by blending light sphagnum peat $\left(\mathrm{H}_{2-3}\right.$ on the Von Post decomposition scale) (32) received from Sungro, Horticulture Canada, Ltd., Lamaque, N.B., Canada, with coarse horticultural grade perlite (Ball Seed Co., West Chicago, IL), starter fertilizer, and dolomitic lime as described by Horst et al. (19). The mix was inoculated with a granular dry powder conidial preparation of T. hamatum 382 (received from Sylvan Bioproducts, Inc., Kittanning, PA) at a rate of mix of $120 \mathrm{~g} \mathrm{~m}^{-3}$ to establish an initial population density for $T$. hamatum 382 of at least $2 \times 10^{5} \mathrm{CFU} \mathrm{g}^{-1}$ dry weight mix, as described by Horst et al. (19). Control potting mix was not inoculated with T. hamatum 382. The total putative population of $T$. hamatum 382 in both mixes was determined by suspending $10 \mathrm{~g}$ (wet weight) of potting mix subsamples (three replicates per treatment) into $90 \mathrm{ml}$ of dilution buffer $(7.0 \mathrm{~g}$ of $\mathrm{K}_{2} \mathrm{HPO}_{4}, 3.0 \mathrm{~g}$ of $\mathrm{KH}_{2} \mathrm{PO}_{4}$, and $1.5 \mathrm{~g}$ of Difco potato dextrose agar liter $^{-1}$ ). This suspension was homogenized for $30 \mathrm{~s}$, diluted, and then plated in triplicate on a Trichoderma selective medium (8). Phialides produced by Trichoderma isolates after 10 days of incubation on the medium, as viewed by light microscopy, served to verify the identity of $T$. hamatum according to Bissett (5). The incidence of $T$. hamatum 382 among these T. hamatum isolates (two colonies per replicate for each potting mix sample; $n=6$ ) was confirmed using the polymerase chain reaction (PCR) with T. hamatum 382-specific PCR primers $\left(\mathrm{SCE}_{347}\right.$ and $\left.\mathrm{SCH} 19_{388}\right)$ as described previously (1).

Bacterial leaf spot bioassay. Control and inoculated potting mixes were incubated for 7 days at $24^{\circ} \mathrm{C}$ and then seeded with tomato (Solanum lycopersicum L.) cv. Ohio 8245 (4) (supplied by D. M. Francis, Department of Horticulture and Crop Sciences, The Ohio State University, Wooster) in 400-ml, 10-cm-tall pots (two seeds per pot). 'Ohio' 8245 is susceptible to $X$. euvesicatoria 110c. Seeded pots were placed in a greenhouse under natural summer light conditions with day and night temperatures within the range of 22 to 34 and 18 to $27^{\circ} \mathrm{C}$, respectively. The number of emerged seedlings was reduced to one per pot after 7 days. Plants were irrigated daily and fertilized three times per week with Peters 20-20-20 soluble fertilizer plus minors (Grace-Sierra Chemical Co., Milpitas, CA) at a concentration of $150 \mu \mathrm{g} \mathrm{ml}^{-1}$. This maintained foliar nutrient concentrations within the range recommended for greenhouse tomato production (28). A preliminary experiment established that the foliar concentrations of essential nutrients, with the exception of sulphur (S), of plants produced in the control and the mix inoculated with $T$. hamatum 382 did not differ significantly $(P=$ 0.05 , data not shown). The concentration of $\mathrm{S}$ in plants produced in the mix inoculated with T. hamatum 382 was higher than in plants produced in nonamended mix. During the fifth week after planting, when the seventh leaf on each plant had fully expanded, plants were overhead misted intermittently to wet the foliage and maintain a relative humidity close to the saturation range. This provided optimum conditions for inoculation and infection of plants with $X$. euvesicatoria 110c (33), a strain resistant to streptomycin sulphate.

$X$. euvesicatoria $110 \mathrm{c}$ was cultured for $48 \mathrm{~h}$ at $28^{\circ} \mathrm{C}$ on yeast dextrose carbonate (YDC) medium (26), washed from agar plates with sterilized distilled water, and diluted further with distilled water to yield $\approx 1 \times 10^{8} \mathrm{CFU} \mathrm{ml}^{-1}$ (optical density at $600 \mathrm{~nm}$ was $\approx 0.2$ ). The concentration of $X$. euvesicatoria $110 \mathrm{c}$ in this inoculum was verified by dilution plating on a Xanthomonas-selective (CKTM) medium (37). The entire aboveground portion of plants was sprayed to run-off with this suspension during the fifth week after seeding. Control plants were sprayed with sterilized distilled water. The population of $X$. euvesicatoria $110 \mathrm{c}$ on tomato leaflets immediately after inoculation was determined by macerating the second leaflet of the third leaf (two plants per treatment) with a ball-bearing tissue grinder (BioReba AG, Basel, Switzerland) in a polyethylene bag containing $5 \mathrm{ml}$ of sterilized dilution buffer $\left(\mathrm{K}_{2} \mathrm{HPO}_{4}\right.$ at $7.0 \mathrm{~g} / \mathrm{liter}, \mathrm{KH}_{2} \mathrm{PO}_{4}$ at $3.0 \mathrm{~g} / \mathrm{liter}$, and Difco potato dextrose agar at $1.5 \mathrm{~g} /$ liter) according to Sahin and Miller (33). Serial 10-fold dilutions then were plated in triplicate onto CKTM medium. After 5 days of incubation at $28^{\circ} \mathrm{C}$, colonies were counted and the population of $X$. euvesicatoria $110 \mathrm{c}$ was expressed as $\log \mathrm{CFU} \mathrm{\textrm {g } ^ { - 1 }}$ fresh weight of tissue of control and inoculated plants.

Two bacterial spot experiments were performed. In the first experiment, six blocks of one plant per treatment (control mix and the mix inoculated with $T$. hamatum 382) were inoculated with $X$. euvesicatoria 110c. Pathogen control plants (not inoculated with $X$. euvesicatoria 110c) included six blocks of two plants per treatment (control mix and the mix inoculated with $T$. hamatum 382). All treatments were completely randomized within each block. In the second experiment, plants were inoculated with seven different densities of $X$. euvesicatoria $110 \mathrm{c}$ inoculum $(0,1 \times$ $10^{6}, 3 \times 10^{6}, 1 \times 10^{7}, 3 \times 10^{7}, 1 \times 10^{8}$, and $3 \times 10^{8} \mathrm{CFU} \mathrm{ml}{ }^{-1}$ ) utilizing four blocks of three plants per treatment. Treatments were fully randomized within each block. They included the potting mix control, the mix inoculated with T. hamatum 382, and the seven pathogen inoculum density treatments.

The severity of bacterial leaf spot on the first, second, third, fifth, sixth, and seventh leaf of each plant was rated separately in each experiment. In the first experiment, plants were rated on days $7,10,12$, and 14 post inoculation using a modified HorsfallBarratt rating scale (18) in which $1=$ symptomless, $2=1$ to $3 \%$, $3=4$ to $6 \%, 4=7$ to $12 \%, 5=13$ to $25 \%, 6=26$ to $50 \%, 7=51$ to $75 \%, 8=76$ to $87 \%, 9=88$ to $94 \%$, and $10=95$ to $97 \%$ of the total leaf area affected by the disease; $11=98$ to $99 \%$ of the total leaf area affected by disease and severe yellowing; and $12=$ dead leaf. In the second experiment, they were rated on days 6, 7, 8, 9, 11, and 14 (postinoculation). At 12 days after inoculation, the population of $X$. euvesicatoria $110 \mathrm{c}$ in tomato leaves of control and inoculated plants was determined by harvesting the terminal 
leaflet of the third leaf of each plant. Each leaflet was macerated in dilution buffer and plated on CKTM medium as described above to determine the population of $X$. euvesicatoria $110 \mathrm{c} \mathrm{g}^{-1}$ fresh weight of tissue.

Population of T. hamatum 382 in potting mixes and plants. The population of T. hamatum 382 in potting mixes was determined by dilution plating on the selective Trichoderma medium immediately after planting and at weekly intervals thereafter until the completion of each experiment, as described above. At the end of the experiment, when the last disease severity rating had been completed, the presence of T. hamatum 382 in roots and stems was determined for eight randomly chosen plants per treatment. The incidence of $T$. hamatum 382 was determined by plating thoroughly rinsed (with sterilized distilled water) $0.5 \mathrm{~cm}$ root sections (five sections per plant) onto the selective Trichoderma medium. After removing all leaves, $1 \mathrm{~mm}$ stem sections were cut at 5 and $15 \mathrm{~cm}$ above the soil level, washed in distilled water, and plated onto the selective Trichoderma medium. After 10 days of incubation at $25^{\circ} \mathrm{C}$, hyphal tips of putative T. hamatum 382 isolates were transferred to potato dextrose broth. Cultures were grown for 5 days at room temperature without shaking, and the mycelium was filtered through Whatman no. 1 paper, air dried for $24 \mathrm{~h}$ at room temperature, and ground into a fine powder using liquid nitrogen. DNA was extracted from ground mycelium using the procedure described by Lee and Taylor (25) and PCR was performed to verify their identity as described above. The mean incidence of $T$. hamatum 382 in root and stem sections was calculated.

Plant dry weight. Mean plant dry weight was determined at the end of the experiment. The stem of plants (one plant for each of six blocks per potting mix treatment) not inoculated with $X$. euvesicatoria $110 \mathrm{c}$ was cut at the soil line and the aboveground part then was dried at $70^{\circ} \mathrm{C}$ until a constant dry weight was reached.

RNA extraction procedure. During the fifth week after planting, when the seventh leaf on each plant (six plants per treatment) had fully expanded, the fourth leaf was harvested, immediately frozen in liquid nitrogen, and stored at $-70^{\circ} \mathrm{C}$ for extraction of RNA. RNA was extracted from $-70^{\circ} \mathrm{C}$ frozen leaves with a Qiagen RNeasy Mini Kit (Qiagen Inc., CA) according to the manufacturer's instructions. Briefly, frozen leaves were ground separately with a sterilized mortar and pestle. Thereafter, $100 \mathrm{mg}$ of ground leaf tissue was placed into an RNase-free 2-ml microcentrifuge tube to which $450 \mu \mathrm{l}$ of Qiagen RLT buffer ( $1 \% \beta$ mercaptoethanol) was added. The tube was shaken vigorously and the lysate was transferred into a 2-ml collection tube and centrifuged for $2 \mathrm{~min}$ at maximum speed in a QIA shredder spin column. The supernatant then was transferred from the flowthrough fraction to a new microcentrifuge tube and $450 \mu \mathrm{l}$ of 95 to $100 \%$ ethanol was added to the lysate. This solution was mixed by pipetting and transferred to a new RNase-free mini column in a 2-ml microcentrifuge tube and centrifuged for $15 \mathrm{~s}$ at $8,160 \times g$. Thereafter, $700 \mu$ l of Qiagen RW1 buffer was added to the column in the tube and it was centrifuged again for $15 \mathrm{~s}$ at $8,160 \times g$ to wash the column. Next, the column was transferred to a new 2-ml collection tube and $500 \mu \mathrm{l}$ of Qiagen RPE buffer was added. The tube again was centrifuged for $15 \mathrm{~s}$ at $8,160 \times g$. Finally, $500 \mu \mathrm{l}$ of Qiagen RPE buffer was added to the tube and centrifuged for another $2 \mathrm{~min}$ at $8,160 \times g$. The RNA column then was placed into a new 2-ml collection tube and centrifuged for $1 \mathrm{~min}$ at full speed. To elute RNA, the column was transferred into a new $1.5-\mathrm{ml}$ collection tube and $50 \mu \mathrm{l}$ of RNA free water was added directly into the column. It was centrifuged for $1 \mathrm{~min}$ at $8,160 \times g$ and the quantity of RNA recovered was determined at $260 \mathrm{~nm}$ with a densitometer (model 8452A, Hewlett Packard Diode Array Spectrophotometer; Hewlett-Packard Company, Sunnyvale, CA).

NimbleGen microarray analysis. The microarrays were developed in collaboration with S. A. Hogenhout and E. K. van der
Knaap (OARDC, Ohio State University, Wooster) using the platform of NimbleGen Systems, Inc. (Madison, WI) (29). In total, 15,925 tomato unigenes obtained from the TIGR Tomato Gene Index database were represented on the microarrays by 12 24-mer oligonucleotides per gene. RNA samples were submitted to NimbleGen and hybridized as described elsewhere (29). A full description of this tomato microarray will be reported elsewhere.

Bioassay data analysis. The experimental design for disease response to pathogen and biocontrol agent was a repeated measures factorial, with two "crossed factors," T. hamatum 382 (inoculated or not) and X. euvesicatoria 110c pathogen (inoculated or not), and two "repeated factors," time of disease rating and leaf position. For analyses, the lower three and upper three leaves were pooled separately to form a two-level leaf-position factor. A nonparametric marginal effects analysis $(6,35)$ was used to determine the effects of pathogen, biocontrol agent, time, leaf position, and their interactions on disease rating. The method involves, in part, ranking the data and calculating relative marginal effects for all factor levels. The median disease rating was determined for all factor levels, but the significance of effects was determined entirely based on the estimated relative marginal effects (35).

The effect of T. hamatum 382 on leaf population density of $X$. euvesicatoria $110 \mathrm{c}$ was determined with a generalized linear model (12), by specifying a negative binomial distribution for CFU. The effect of T. hamatum 382 on plant dry weight and foliar nutrient concentration was determined with analysis of variance.

Microarray data analysis. Data analysis for identification of differentially expressed genes was performed by regression analysis using the SAS software package (version 8; SAS Institute, Cary, NC). We performed a separate regression analysis for every possible combination of $T$. hamatum 382 versus control treatments. The four possible comparisons (two each for $T$. hamatum 382 and the control treatments) were analyzed separately by using the log-transformed "raw" expression values as input data. For regression analysis, expression data of the T. hamatum 382 treatment (Y-axis) was plotted against the expression data of the control treatment (X-axis) and by setting a $99 \%$ confidence interval. Genes that fell out of this interval were designated as being differentially expressed. Genes that were consistently differentially expressed between the T. hamatum 382 and control treatment in all four regression analyses were selected and used for hierarchical cluster analysis. For clustering purposes, data from all T. hamatum 382 versus control treatment comparisons were compiled, including the tentative consensus (TC) number, and expression value ratios. Cluster analysis was performed using the Cluster software package. First, genes were organized among treatments based on the log-transformed expression ratios using the self-organizing map (SOM) algorithm. The generated output file was used as input file for average linkage hierarchical clustering in both dimensions and data was visualized in Java TreeView 1.0.8. Finally, putative identities of significantly up- or downregulated genes were obtained using BLASTX searches against the GenBank nonredundant (nr) database and by consulting the TIGR Tomato Gene Index database.

Reverse-transcription PCR analyses. Reverse-transcription (RT)-PCR was performed on selected genes to validate the microarray experiments. Total RNA was isolated from the treatments and control samples as described above. Genomic DNA contamination was removed from the total RNA using the Ambion DNAfree kit (Ambion Inc., Austin, TX) following the manufacturer's instructions. cDNAs were synthesized from $1.5 \mu \mathrm{g}$ of total RNA using the ThermoScript RT-PCR system (Invitrogen, Carlsbad, $\mathrm{CA}$ ). Reactions were performed according to the manufacturer's instructions and incubated at $50^{\circ} \mathrm{C}$ for $60 \mathrm{~min}$ followed by $85^{\circ} \mathrm{C}$ for $5 \mathrm{~min}$. cDNA was treated with Rnase $\mathrm{H}(1 \mu \mathrm{l})$ for $20 \mathrm{~min}$ at $37^{\circ} \mathrm{C}$ to remove any contaminating RNA. PCR amplifications were carried out in 25- $\mu \mathrm{l}$ reactions using equal amounts of cDNAs 
( $1 \mu \mathrm{l})$ as template with gene-specific primers (Table 1) on the following gene sequences: TC124403 (extensin), TC124404 (extensin), TC116429 (osmotin-like), TC118045 (fibrillarin), TC124422 (phosphate induced), TC116430 (osmotin-like), TC125376 (expansin), TC122654 (MYB transcriptor factor), and TC122706 ( $\beta$-tubulin). Gene-specific primers were designed using the software Amplify 3.1 (University of Wisconsin-Madison). PCR was performed in a MJR PTC-100 thermocycler (MJ Research Inc., Waltham, MA) using the following conditions: $1 \mathrm{~min}$ at $94^{\circ} \mathrm{C} ; 30$ cycles of $15 \mathrm{~s}$ at $94^{\circ} \mathrm{C}, 30 \mathrm{~s}$ at $55^{\circ} \mathrm{C}(\mathrm{TC} 116429$, TC124403, TC125376, TC116430, TC124422, and TC122706) or $43^{\circ} \mathrm{C}$ (TC124404, TC122654, and TC118045), and $1 \mathrm{~min} 45 \mathrm{~s}$ at $72^{\circ} \mathrm{C}$; and then a 10 -min final extension at $72^{\circ} \mathrm{C}$. cDNA template was undiluted for TC124403 and TC1244, diluted 1:10 for TC124422 and 118045, and diluted 1:50 for the remaining genes amplified. Equal amounts of PCR products were separated by horizontal gel electrophoresis in $1.5 \%$ agarose in $0.5 \times$ Tris-borate EDTA buffer at $100 \mathrm{~V}$ for $60 \mathrm{~min}$. Gels were stained in dilute ethidium bromide solution $(2 \mu \mathrm{g} / \mathrm{ml})$, destained in deionized water, visualized under UV light, and photographed using the Kodak Electrophoresis Documentation and Analysis System 290 (Eastman Kodak Company, New Haven, CT).

\section{RESULTS}

Effect of T. hamatum 382 on bacterial spot severity. The nonparametric marginal effects analysis indicated significant $(P<$ 0.05 ) effects on disease severity in both experiments for the pathogen (not inoculated with $X$. euvesicatoria 110c versus inoculated in the first experiment; not inoculated and different pathogen densities in the second experiment), the biocontrol agent
T. hamatum 382, time after inoculation, and leaf position. Several two-way and three-way interactions were observed as well which, among other things, indicated that the effect of T. hamatum 382 on disease varied with time or leaf position as well as with pathogen inoculation. Thus, comparisons of relative marginal effects were based on the interaction values. Separate comparisons among the pathogen, biocontrol agent, and leafposition interaction values were developed for each diseaseassessment time.

In both experiments, the severity of bacterial spot on plants produced in the potting mix inoculated with T. hamatum 382 was significantly $(P<0.05)$ lower than that on those in the control peat mix. Differences were most pronounced in the first experiment, when greenhouse temperatures ranged from 22 to $30^{\circ} \mathrm{C}$ (Table 2). At 12 and 14 days after inoculation, the severity of bacterial spot on the lower leaves was significantly $(P<0.05)$ lower on plants produced in the mix inoculated with T. hamatum 382 compared with the control mix. On the upper leaves, where disease severity values were significantly lower $(P<0.05)$, T. hamatum 382 had a significant $(P<0.05)$ effect on days 10,12 , and 14 after inoculation. In the second experiment, when greenhouse temperatures were higher and ranged from 25 to $34^{\circ} \mathrm{C}$ and where six different inoculum densities of $X$. euvesicatoria $110 \mathrm{c}$ in addition to the noninoculated control were used, inoculum density apart from the control did not have a significant $(P<0.05)$ effect. Therefore, disease severity values included in the overall data analysis for the second experiment were for the same inoculum densities as those used in experiment 1 (X. euvesicatoria $110 \mathrm{c}$ at 0 and $\left.1 \times 10^{8} \mathrm{ml}^{-1}\right)$. In this experiment also, T. hamatum 382 significantly $(P<0.05)$ suppressed the severity of bacterial spot on days $6,7,8,9$, and 11 after inoculation on both lower and

TABLE 1. Gene-specific primer sequences used in reverse-transcription polymerase chain reaction experiments

\begin{tabular}{|c|c|c|c|}
\hline Gene & Putative identity & Forward primer $\left(5^{\prime}\right.$ to $\left.3^{\prime}\right)$ & Reverse primer $\left(5^{\prime}\right.$ to $\left.3^{\prime}\right)$ \\
\hline TC124404 & Extensin & CACTATGTTTACTCСТCTCCC & CATATGGGAGTAGTAATAAC \\
\hline TC124403 & Extensin & CACTATGTTTACTCCTCTCCC & TTCGTCTGATCTTCTGTAAG \\
\hline TC116429 & Osmotin-like & GACTTACACTTATGGTTCCG & CACCGTTTATATTGGCTGTGC \\
\hline TC1 16430 & Osmotin-like & TTGGTGCCAGACCG & AGTACTTGTTGGATCGTC \\
\hline TC118045 & Fibrillarin & GAACATGGCTAAGAAAC & AATCCATTACACTTCCATC \\
\hline TC124422 & Phosphate induced & TACTACCATCTCGCTAATTC & GCAGCTTCCAATGGCG \\
\hline TC125376 & Expansin & GTATCGTCCCTGTATCTTTTCG & CСТАСТСАССССТTTTATGCC \\
\hline TC122654 & MYB transcriptor factor & CCTACCAATGATAGAA & ATGGTACACACACCTACACG \\
\hline TC122706 & $\beta$-Tubulin & ATCGCATCCGAAAGCTTGCAG & ACATCAACATTCAGAGCTCCATC \\
\hline
\end{tabular}

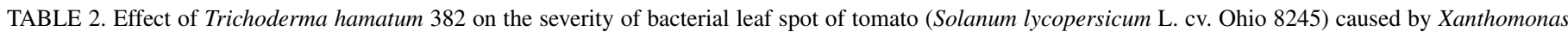
euvesicatoria in a light sphagnum peat potting mix

\begin{tabular}{|c|c|c|c|c|c|c|c|c|c|}
\hline \multirow[b]{3}{*}{ Part, treatment ${ }^{\mathrm{y}}$} & \multirow[b]{3}{*}{ Inoculum $^{\mathrm{Z}}$} & \multicolumn{8}{|c|}{ Disease severity (days after inoculation) ${ }^{\mathrm{x}}$} \\
\hline & & \multicolumn{2}{|c|}{7} & \multicolumn{2}{|c|}{10} & \multicolumn{2}{|c|}{12} & \multicolumn{2}{|c|}{14} \\
\hline & & Rating & Effect & Rating & Effect & Rating & Effect & Rating & Effect \\
\hline \multicolumn{10}{|l|}{ Upper leaves } \\
\hline \multirow[t]{2}{*}{ Control } & - & 1.00 & $0.25 \mathrm{a}$ & 1.00 & $0.25 \mathrm{~b}$ & 1.00 & $0.25 \mathrm{c}$ & 1.00 & $0.25 \mathrm{~b}$ \\
\hline & + & 4.17 & $0.61 \mathrm{~cd}$ & 5.17 & $0.69 \mathrm{~d}$ & 5.67 & $0.68 \mathrm{e}$ & 6.33 & $0.71 \mathrm{~d}$ \\
\hline \multirow[t]{2}{*}{ T. hamatum 382} & - & 1.00 & $0.25 \mathrm{a}$ & 1.00 & $0.25 \mathrm{~b}$ & 1.00 & $0.25 \mathrm{c}$ & 1.00 & $0.25 \mathrm{~b}$ \\
\hline & + & 3.83 & $0.56 \mathrm{~d}$ & 3.67 & $0.54 \mathrm{a}$ & 3.67 & $0.54 \mathrm{a}$ & 4.17 & $0.59 \mathrm{a}$ \\
\hline \multicolumn{10}{|l|}{ Lower leaves } \\
\hline \multirow[t]{2}{*}{ Control } & - & 1.00 & $0.25 \mathrm{a}$ & 1.00 & $0.25 \mathrm{~b}$ & 1.67 & $0.35 \mathrm{~b}$ & 1.00 & $0.25 \mathrm{~b}$ \\
\hline & + & 5.67 & $0.67 \mathrm{bc}$ & 11.00 & $0.91 \mathrm{c}$ & 11.50 & $0.93 \mathrm{~d}$ & 11.67 & $0.94 \mathrm{c}$ \\
\hline \multirow[t]{2}{*}{ T. hamatum 382} & - & 1.00 & $0.25 \mathrm{a}$ & 1.00 & $0.25 \mathrm{~b}$ & 1.67 & $0.36 \mathrm{~b}$ & 1.00 & $0.25 \mathrm{~b}$ \\
\hline & + & 6.00 & $0.71 \mathrm{~b}$ & 10.17 & $0.87 \mathrm{c}$ & 10.83 & $0.89 \mathrm{f}$ & 11.00 & $0.90 \mathrm{e}$ \\
\hline
\end{tabular}

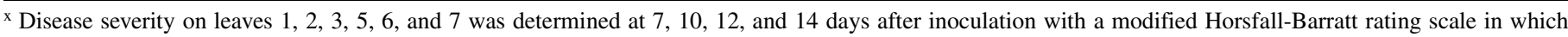
$1=$ symptomless and $12=$ dead leaf. Disease severity values of the lower $(1,2$, and 3$)$ and upper (5, 6, and 7) leaves were combined to determine median rating values. Rating = median rating and Effect = estimated relative marginal effect (33) based on the mean rank and ranges from 0 to 1 . Significance of factors or their interactions was based on a nonparametric marginal effects analysis (6). Means followed by the same letter in each column do not differ significantly according to Fisher's least significant difference at $P=0.05$.

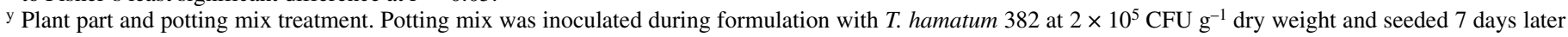
(two blocks of three pots per treatment, one plant per pot; $n=6$ ). Control was not inoculated.

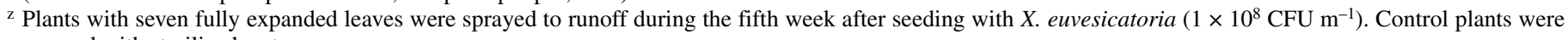
sprayed with sterilized water. 
upper leaves. However, differences on lower and upper leaves were not significant $(P=0.05)$ on day 14 after inoculation. Control plants (not inoculated with $X$. euvesicatoria $110 \mathrm{c}$ ) in both potting mixes ( $T$. hamatum 382 and control treatments) remained free of symptoms. Data for experiment 2 are not presented in table format because they did not differ substantially from that of experiment 1 .

Effect of T. hamatum 382 on population of $X$. euvesicatoria $110 \mathrm{c}$ in tomato foliage. The population of $X$. euvesicatoria $110 \mathrm{c}$ recovered on CKTM medium from plants inoculated with the pathogen in the first experiment that had been produced in the potting mix inoculated with $T$. hamatum $382\left(6.1 \times 10^{7} \mathrm{CFU} \mathrm{g}^{-1}\right.$ fresh weight of tissue) was significantly $(P<0.03)$ lower than in control plants $\left(1.4 \times 10^{8} \mathrm{CFU} \mathrm{\textrm {g } ^ { - 1 }}\right.$ fresh weight of tissue $)$ inoculated with $X$. euvesicatoria $110 \mathrm{c}$. In the second experiment, its population in diseased leaves of plants produced in the potting mix inoculated with $T$. hamatum 382 (X. euvesicatoria $110 \mathrm{c}$ at $1.5 \times 10^{7} \mathrm{CFU} \mathrm{g}^{-1}$ fresh weight of tissue) also was significantly ( $P$ $=0.0002)$ lower than in the control mix $(X$. euvesicatoria $110 \mathrm{c}$ at $2.3 \times 10^{7} \mathrm{CFU} \mathrm{\textrm {g } ^ { - 1 }}$ fresh weight of tissue). In both experiments, the pathogen was not isolated from leaflets of control plants (not inoculated with $X$. euvesicatoria $110 \mathrm{c}$ ).

Populations of T. hamatum 382 in potting mixes and plants. In the first experiment, the mean putative T. hamatum 382 population isolated on the selective medium at planting from the potting mix inoculated with $T$. hamatum 382 was $7.0 \times 10^{5} \mathrm{CFU}$ $\mathrm{g}^{-1}$ dry weight of potting mix (Fig. 1). It remained at that population thereafter, with little variation among samples, until plants were harvested after 50 days. PCR confirmed all tested isolates as T. hamatum 382. Several Trichoderma spp., including T. hamatum and $T$. harzianum, were isolated from the control potting mix. In the first experiment, mean putative $T$. hamatum 382 populations in the control mix ranged from $<10$ to $2 \times 10^{3} \mathrm{CFU} \mathrm{g}^{-1}$ dry weight of potting mix (Fig. 1). PCR confirmed that $82.4 \%$ of these isolates were T. hamatum 382. Similar trends in T. hamatum 382 populations were observed in both potting mixes in experiment 2 .

T. hamatum 382 was consistently isolated from root sections of plants harvested from the potting mix inoculated with T. hamatum 382 based on morphological characteristics on the selective medium and PCR of selected isolates. It was not recovered from the root sections of control plants (produced in the mix not inoculated with $T$. hamatum 382). Trichoderma isolates were not recovered on the selective medium from any of the stem cross sections harvested from plants at 5 and $15 \mathrm{~cm}$ above the soil line, regardless of potting mix treatment.

Effect of T. hamatum 382 on shoot dry weight. The mean plant dry weight at 43 days after seeding of plants produced in the potting mix inoculated with $T$. hamatum 382 was $7.15 \pm 0.68 \mathrm{~g}$. The mean dry weight of control plants $(7.27 \pm 1.34 \mathrm{~g})$ did not differ significantly $(P<0.05)$ from that of plants produced in the mix inoculated with $T$. hamatum 382 . These results were consistent among experiments.

Systemic induction of tomato gene expression by $T$. hamatum 382. We performed gene expression profiling by hybridizing RNA extracted from leaves of T. hamatum 382-treated and untreated control tomato plants to a custom-made tomato oligonucleotide chip. In all, four hybridizations were performed, corresponding to two biological replicates obtained from independently cultivated and inoculated plants as well as two technical replicates. We elected to perform stringent data analysis to identify genes that exhibited differential expression in all four hybridizations. Normalized data were subjected to regression analysis and outlier detection, resulting in lists of genes that were significantly up- or downregulated based on a $99 \%$ confidence interval. We classified genes as up- or downregulated when they showed a significant difference in expression levels in four comparisons of the untreated control versus T. hamatum 382 treatments. In total, 47 genes were differentially expressed based on these criteria in all comparisons. Of the 47 genes, 2 were removed from the dataset because they showed inconsistent expression ratios across the T. hamatum 382 versus the untreated control comparisons. The expression ratios ( $T$. hamatum $382 /$ control) of the remaining 45 genes were used as input for hierarchical cluster analyses. Two major clusters of genes were identified. One cluster consisted of 36 T. hamatum 382 upregulated genes (Table 3 ) whereas the other cluster consisted of 9 downregulated genes (Table 4).

We obtained putative identities for the 45 differentially expressed genes using BLASTX searches against GenBank nonredundant database and by consulting the TIGR Tomato Gene Index database. A putative identity could be assigned to 41 of the 45 genes (Tables 3 and 4). These could be classified into seven functional categories that included physiological states related to stress, cell wall modification, and signaling as well as RNA, DNA, and protein metabolism. Genes that had known functions but could not be placed in a particular functional category were compiled in a separate class.

Validation of microarray experiments using semiquantitative RT-PCR. We selected eight genes for RT-PCR analyses to independently validate the microarray experiments (Materials and Methods). We also included tomato $\beta$-tubulin as a constitutive control. Overall, there was a positive correlation between the intensity of the RT-PCR bands and the expression values obtained in the microarray experiments (Fig. 2). Three genes, TC124404 (extensin), TC125376 (expansin), and TC122654 (MYB transcriptor factor), showed distinct differences in RT-PCR band intensity between the two T. hamatum 382 treatments versus the untreated controls. The other five genes showed differences between the T. hamatum 382 and control treatments that were consistent with the up- or downregulations determined with the microarrays. However, the differences in band intensity either were not very large or were not consistent across the two biological replicates. In general, these results showed that the RTPCR data supported the microarray findings.

\section{DISCUSSION}

Prior to the microarray experiments, we established that T. hamatum 382 consistently induced protection in tomato against bacterial spot without affecting plant growth. Furthermore, the population of the pathogen (X. euvesicatoria 110c) in tomato

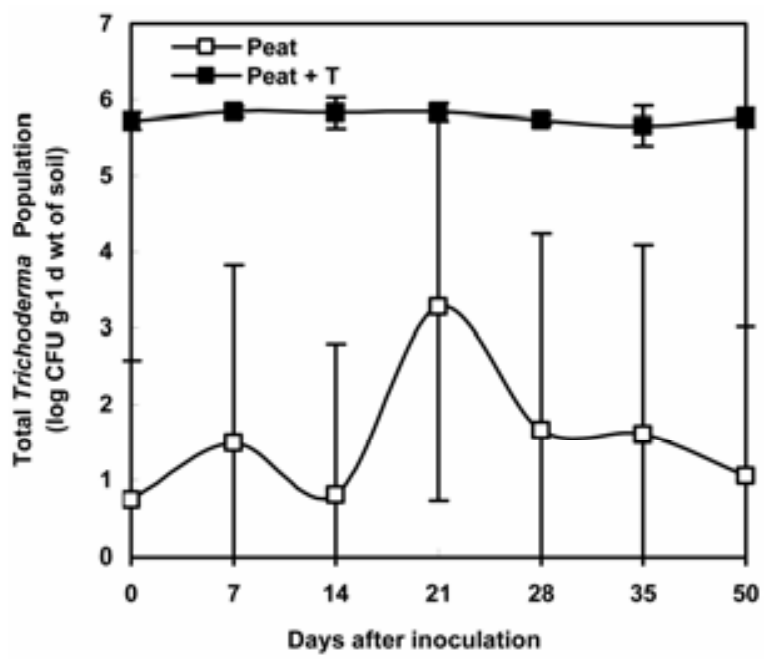

Fig. 1. Trends in total Trichoderma populations in the control peat mix (Peat) and the mix inoculated with Trichoderma hamatum $382($ Peat $+\mathrm{T})$. Conidial inoculum of T. hamatum 382 was added to the inoculated mix to establish an initial population of $T$. hamatum 382 of at least $2 \times 10^{5} \mathrm{CFU} \mathrm{g}^{-1}$ dry weight mix; the control mix was not inoculated. Both mixes were planted 7 days later with tomato seedlings. Bars represent standard errors $(n=9)$. 
leaves was suppressed significantly $(P=0.05)$ in plants produced in the potting mix inoculated with T. hamatum 382 . This suggests that the biocontrol agent increased the resistance of the plant to the disease. The low and variable level of control provided by $T$. hamatum 382 in this work is typical of the subtle differences in foliar disease severity described for plants produced in light sphagnum peat or compost-amended container media $(17,19,23$, 24,30,47).

In order for the protective effect induced by T. hamatum 382 in tomato to be due to systemic activity, as mentioned earlier, it is imperative and also critical to the objectives of this work that the inducer remain spatially separated from the pathogen $(X$. euvesicatoria 110c) in the host plant (31). Based on isolations on the
Trichoderma selective medium and on PCR results, T. hamatum 382 was consistently recovered from roots of plants grown in the potting mix inoculated with this biocontrol agent but not from leaves or stem sections of the same plants. Furthermore, tomato leaflets from which RNA was extracted were harvested and frozen just before plants were inoculated with $X$. euvesicatoria $110 \mathrm{c}$. Thus, spatial separation between the pathogen and the biocontrol agent was maintained, indicating that the suppressive effect induced in tomato against bacterial spot was due to systemic activity induced by T. hamatum 382 and not as a result of contamination with the pathogen.

The biocontrol agent T. hamatum 382 apparently disseminated naturally from the inoculated to the control mix because low

TABLE 3. Overview of tomato (Solanum lycopersicum L. cv. Ohio 8245) genes upregulated in leaves following root treatment with Trichoderma hamatum 382y

\begin{tabular}{|c|c|c|c|c|c|c|}
\hline $\mathrm{TC}$ number & Putative identity & Functional category ${ }^{\mathrm{z}}$ & T1 vs. C1 & T1 vs. C2 & T2 vs. $\mathrm{C} 1$ & $\mathrm{~T} 2$ vs. $\mathrm{C} 1$ \\
\hline TC116429 & Osmotin-like protein, pathogenesis-related protein PR-5 & Stress & 3.4 & 3.1 & 3.1 & 2.8 \\
\hline TC116430 & Osmotin-like protein, similar to pathogenesis-related protein PR-5 & Stress & 5.7 & 3.2 & 4.3 & 2.4 \\
\hline TC124422 & Phosphate-induced protein & Stress & 2.5 & 1.9 & 7.8 & 5.9 \\
\hline TC124423 & Phosphate-induced protein & Stress & 2.3 & 1.6 & 7.3 & 5.4 \\
\hline TC122281 & Salt-induced protein & Stress & 2.1 & 1.8 & 2.2 & 1.9 \\
\hline TC127846 & Salt-induced protein & Stress & 2.0 & 1.8 & 2.6 & 2.3 \\
\hline TC124403 & Extensin & Cell wall, stress & 5.7 & 2.9 & 6.3 & 3.2 \\
\hline TC124404 & Extensin & Cell wall, stress & 4.9 & 2.6 & 5.6 & 3.0 \\
\hline TC118157 & Extensin-like protein, similar to arachidonic acid-induced DEA1 & Cell wall, stress & 3.0 & 1.9 & 2.7 & 1.7 \\
\hline TC127619 & Extensin-like protein, similar to arachidonic acid-induced DEA1 & Cell wall, stress & 2.3 & 4.3 & 4.0 & 7.6 \\
\hline TC120522 & Chlorplastic RNA binding protein, similar to salt-induced protein & RNA metabolism, stress & 2.2 & 1.8 & 2.4 & 2.0 \\
\hline TC124950 & Glycine-rich protein, nucleolin & RNA metabolism, stress & 2.1 & 1.8 & 2.4 & 2.2 \\
\hline TC126697 & Glycine-rich RNA-binding protein & RNA metabolism, stress & 2.6 & 1.8 & 2.5 & 1.7 \\
\hline TC119182 & Glycine-rich RNA-binding protein & RNA metabolism, stress & 2.1 & 1.8 & 2.1 & 1.7 \\
\hline TC119704 & Nonsense-mediated mRNA decay protein & RNA metabolism & 1.8 & 2.0 & 3.0 & 3.3 \\
\hline TC125742 & RNA-binding protein & RNA metabolism & 2.7 & 1.7 & 3.9 & 2.4 \\
\hline TC118518 & Histone H3 & DNA metabolism & 2.0 & 1.7 & 3.2 & 2.6 \\
\hline TC124360 & Acidic ribosomal protein & Protein metabolism & 2.6 & 1.7 & 3.9 & 2.5 \\
\hline TC123773 & Elongation factor & Protein metabolism & 2.3 & 2.6 & 3.7 & 4.0 \\
\hline TC116525 & Ribosomal protein L33 & Protein metabolism & 2.4 & 1.7 & 2.9 & 2.1 \\
\hline TC126955 & Alanine acetyl transferase & Protein metabolism & 2.3 & 3.3 & 3.3 & 4.8 \\
\hline TC122297 & DnaJ chaperone & Protein metabolism & 2.1 & 3.5 & 3.7 & 6.2 \\
\hline TC124153 & Glutathione S-transferase, similar to auxin-induced protein & Protein metabolism & 1.9 & 2.5 & 3.0 & 4.0 \\
\hline TC120960 & Translation initiation factor & Protein metabolism & 3.3 & 1.9 & 6.5 & 3.8 \\
\hline TC124479 & GTP-binding protein & Signaling & 2.3 & 1.6 & 3.3 & 2.4 \\
\hline TC124777 & RING finger protein & Signaling & 4.9 & 3.5 & 4.1 & 2.9 \\
\hline TC118804 & Zinc finger protein & Signaling & 2.2 & 8.5 & 3.5 & 13.7 \\
\hline TC130987 & $\mathrm{ABC}$ transporter & Transport & 1.8 & 2.2 & 2.1 & 2.5 \\
\hline TC122259 & plastidic ATP/ADP-transporter & Transport & 2.1 & 2.1 & 2.0 & 2.0 \\
\hline TC118045 & Fibrillarin & None & 3.1 & 1.9 & 4.3 & 2.6 \\
\hline TC124142 & Flavonol synthase & None & 3.7 & 3.2 & 2.4 & 2.1 \\
\hline TC122197 & Hydroxycinnamoyl transferase & None & 5.5 & 4.2 & 3.2 & 2.4 \\
\hline TC129209 & Oxidoreductase, similar to NADH dehydrogenase & None & 2.0 & 2.2 & 2.6 & 3.0 \\
\hline TC128153 & Phospholipase & None & 3.1 & 4.1 & 3.0 & 4.0 \\
\hline TC121576 & Unknown & None & 2.5 & 3.0 & 2.8 & 3.4 \\
\hline TC131566 & Unknown & None & 2.1 & 1.8 & 2.8 & 2.5 \\
\hline
\end{tabular}

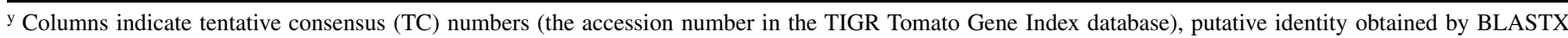
searches of public databases, assigned functional category, and expression ratios for the different Trichoderma (T) versus control (C) treatments.

${ }^{\mathrm{z}}$ None $=$ genes that could not be unambiguously assigned to a functional category.

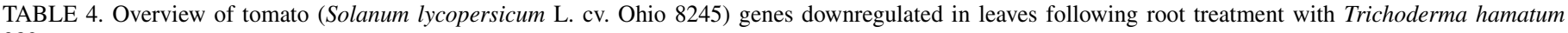
$382^{\mathrm{y}}$

\begin{tabular}{|c|c|c|c|c|c|c|}
\hline TC number & Putative identity & Functional category ${ }^{z}$ & T1 vs. $\mathrm{C} 1$ & T1 vs. C2 & $\mathrm{T} 2$ vs. $\mathrm{C} 1$ & $\mathrm{~T} 2$ vs. C1 \\
\hline TC125376 & Expansin 2 & Cell wall, stress & 0.4 & 0.3 & 0.5 & 0.4 \\
\hline TC118807 & RNA polymerase sigma subunit & RNA metabolism & 0.5 & 0.6 & 0.4 & 0.5 \\
\hline TC129072 & RNA polymerase sigma subunit & RNA metabolism & 0.6 & 0.6 & 0.5 & 0.5 \\
\hline TC118937 & DnaJ chaperone & Protein metabolism & 0.4 & 0.3 & 0.3 & 0.2 \\
\hline TC122654 & MYB transcription factor & Signaling & 0.5 & 0.5 & 0.5 & 0.4 \\
\hline TC129827 & $\mathrm{ABC}$ transporter & Transport & 0.5 & 0.6 & 0.5 & 0.5 \\
\hline TC124092 & Haloacid dehalogenase-like hydrolase & None & 0.5 & 0.4 & 0.5 & 0.4 \\
\hline TC120053 & Unknown & None & 0.6 & 0.5 & 0.4 & 0.4 \\
\hline TC118364 & Unknown & None & 0.4 & 0.6 & 0.3 & 0.5 \\
\hline
\end{tabular}

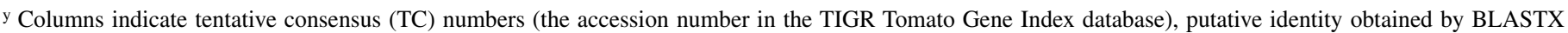
searches of public databases, assigned functional category, and expression ratios for the different Trichoderma (T) versus control (C) treatments.

$\mathrm{z}$ None $=$ genes that could not be unambiguously assigned to a functional category. 
T. hamatum 382 populations were recovered from some samples of this mix in both experiments. However, it consistently was not isolated from root sections of plants harvested from the control mix. The low level of dissemination of T. hamatum 382 to the control treatment observed in this work agrees with earlier findings on limited dissemination of this biocontrol agent in container media (17). Because T. hamatum 382 did not establish high enough populations in the control mix to colonize roots of control plants to detectable levels, these findings further support our conclusion that the suppressive effect against bacterial spot in the inoculated mix was induced by T. hamatum 382 .

To elucidate the mechanism by which T. hamatum 382 induces ISR in tomato, we compared the expression pattern of 15,925 tomato genes in leaves of plants inoculated with T. hamatum 382 with that in control plants and, thus, evaluated systemic modulation of gene expression induced in tomato by this biocontrol agent. We identified 45 genes to be differentially expressed across the replicated treatments. A total of 41 of these genes could be assigned to at least one of seven functional categories. Of the $36 \mathrm{~T}$. hamatum 382-induced genes, 14 have functions associated with biotic or abiotic stress, suggesting that the fungus triggers stress-like physiological responses in tomato. Of notable interest is the three- to fivefold induction of the gene encoding the pathogenesis-related protein PR-5 (TC116429) and a related homolog (TC116430). Other than PR-5, however, marker genes for the SAR pathway were not significantly upregulated even though these genes were represented in the microarray.
The expression of marker genes for the JA defense pathway, such as Loxl, ETR1, and CTR1, was not significantly affected. Thus, our results with T. hamatum 382 in tomato are consistent with findings by Segarra et al. (34), who reported that the concentrations of SA and JA in cucumber roots and cotyledons were not altered significantly by $T$. asperellum T-34. However, we failed to detect the induction of ISR markers as reported for T. asperellum T203 in cucumber (39). T. asperellum T-34, in addition to inducing systemic resistance in cucumber seedlings, also increases growth of such seedlings produced under controlled conditions (46). Possibly, the JA pathway is not induced consistently during the resistance response triggered by Trichoderma strains. On the other hand, the mechanisms by which Trichoderma strains induce systemic resistance in plants to diseases may differ also. Finally, temporal differences in the expression of marker genes for the JA defense pathway as described by Soresh et al. (39) may explain the differences between the findings for T. asperellum T-34 and T. hamatum 382.

Additional differentially expressed stress-related induced genes in leaves of tomato plants inoculated with T. hamatum 382 consisted of phosphate- and salt-induced genes as well as four extensin and extensin-like proteins that function in cell wall structure and plant defense $(36,41)$. The induction of extensins by an ISR-inducing rhizosphere microorganism is consistent with the well-established observation that biocontrol agents induce extensive cell wall changes in plants before penetration of roots by pathogens $(30,43)$. Expression of extensin genes can be triggered by plant pathogens or abiotic factors such as wounding and

\begin{tabular}{|c|c|c|c|c|c|c|}
\hline Gene & Putative identity & T1 T2 C1 C2 To & T1 & $\mathrm{T} 2$ & C1 & $\mathrm{C} 2$ \\
\hline TC124404 & Extensin & $-\ldots$ & 371 & 426 & 76 & 140 \\
\hline $\mathrm{TC} 124403$ & Extensin & 1 & 338 & 375 & 59 & 116 \\
\hline TC116429 & Osmotin-like & & 1198 & 1073 & 348 & 389 \\
\hline TC116430 & Osmotin-like & & 2516 & 1880 & 440 & 775 \\
\hline TC118045 & Fibrillarin & & 1401 & 1969 & 459 & 748 \\
\hline $\mathrm{TC} 124422$ & Phosphate induced & ב & 1194 & 3787 & 483 & 639 \\
\hline TC125376 & Expansin & & 1477 & 1618 & 3308 & 4406 \\
\hline TC122654 & $\begin{array}{l}\text { MYB transcriptor } \\
\text { factor }\end{array}$ & & 1466 & 1237 & 2680 & 3214 \\
\hline TC122706 & $\beta$-tubulin & & 1684 & 1697 & 1426 & 1469 \\
\hline
\end{tabular}

Fig. 2. Validation of the microarray experiments using semiquantitative reverse-transcriptase polymerase chain reaction (RT-PCR). Total genomic DNA from tomato was used as a positive control for PCR amplification. Amplicon size of the tomato gene varies in size based on the number and size of introns present in the gene sequence. Amplification of the $\beta$-tubulin gene (TC122706) was used as a control to determine constitutive levels of expression. T1 and T2: replicate samples of Trichoderma hamatum 382-treated potting mix; C1 and C2: replicated samples of untreated potting mix (untreated controls). Expression values from the microarray experiments are shown on the right. 
exogenously supplied SA and methyl jasmonate $(27,36)$. This link of extensins with induced resistance led to the hypothesis that manipulation of extensin expression could be used as a possible strategy for disease management (36). Indeed, overexpression of the extensin EXTI gene in Arabidopsis has been shown to enhance resistance to the bacterial pathogen Pseudomonas syringae (41). Interestingly, the extensin-like TC118157 and TC127619 show similarity to genes induced by the defense elicitor arachidonic acid, which is in line with the proposed similarity between the responses induced by Trichoderma spp. to those triggered by pathogen elicitors (14).

Yet another 14 upregulated genes were annotated as functioning in RNA, DNA, and protein metabolism. These included genes encoding various RNA-binding proteins, an $\mathrm{H} 3$ histone, as well as various components of protein translation machinery. These results indicate elevated cell metabolism in leaves of induced plants. In these two tomato experiments, as mentioned earlier, we consistently failed to detect changes in plant growth and, based on findings in a preliminary experiment, T. hamatum 382 also did not affect nutrient uptake into tomato foliage, with the exception of the concentration of foliar S, which was increased significantly. These findings agree with earlier reports on T. hamatum 382 which demonstrated that ISR was induced without affecting growth of radish or cucumber $(23,24)$. Under severe disease pressures, however, T. hamatum 382 does increase plant dry weight and flowering $(17,19)$. This supports findings by Harman $(13)$, who reported that an increase in growth induced by Trichoderma spp. is observed most frequently under stress conditions. Lack of an impact of T. hamatum 382 on growth in our experiments, therefore, may have been due to the absence of stress factors and, possibly, the short growth period used in this work (5 weeks). This raises intriguing questions about the extent to which this enhanced metabolic state contributes to disease resistance. Further experiments are needed to address these issues.

In conclusion, our findings strongly support the concept that $T$. hamatum 382 actively induces systemic changes in plant physiology and disease resistance, and complement the changes in gene expression reported by Shoresh et al. (39) with cucumber and T. asperellum T203. The induction of genes involved in stress response and plant cell metabolism by T. hamatum 382 could turn out to be a general feature of ISR-inducing rhizosphere microorganisms. Using Arabidopsis microarrays, Wang et al. (40) showed that the plant growth-promoting rhizobacterium $P$. fluorescens FPT9601-T5 also modulates the expression of stress and metabolism genes. To our knowledge, this is the first report of increased extension expression by an ISR-inducing rhizospere microorganism. The next question is to understand how these changes in the transcriptome result in enhanced systemic disease resistance induced by these microorganisms.

\section{ACKNOWLEDGMENTS}

Salaries and research support were provided by the University of Molise, Campobasso, Italy and by state and federal grants to the Ohio Agricultural Research and Development Center, Ohio State University and to the United States Department of Agriculture-Agricultural Research Service, ATRU, Wooster, OH. We thank L. E. Horst for providing technical assistance, S. A. Hogenhout and E. K. van der Knaap for providing access to the tomato microarray, and B. McSpadden Gardener and $\mathrm{D}$. Rotenberg for reviewing this manuscript.

\section{LITERATURE CITED}

1. Abbasi, A. P., Miller, S. A., Meulia, T., Hoitink, H. A. J., and Kim, J. M. 1999. Precise detection and tracing of Trichoderma hamatum 382 in compost-amended potting mixes by using molecular markers. Appl. Environ. Microbiol. 65:5421-5426.

2. Ahmed, A. S., Sanchez, C. P., and Candela, M. E. 2000. Evaluation of induction of systemic resistance in pepper plants (Capsicum апnиит) to
Phytophthora capsici using Trichoderma harzianum and its relation with capsidol accumulation. Eur. J. Plant Pathol. 106:817-824.

3. Al-Dahmani, J. H., Abbasi, P. A., Sahin, F., Hoitink, H. A. J., and Miller, S. A. 2005. Reduction of bacterial leaf spot severity on radish, lettuce, and tomato plants grown in compost-amended potting mixes. Can. J. Plant Pathol. 27:186-193.

4. Berry, S. Z., and Gould, W. A. 1991. 'Ohio 8245 ' processing tomato. HortScience 26:1093.

5. Bissett, J. 1991. A revision of the genus Trichoderma. II. Intrageneric classification. Can. J. Bot. 69:2357-2372.

6. Brunner, E., and Puri, M. 2001. Nonparametric methods in factorial designs. Stat. Pap. 42:1-52.

7. Chet, I., Benhamou, N., and Haran, S. 1998. Mycoparasitism and lytic enzymes. Pages 153-172 in: Trichoderma and Gliocladium. Volume 2. Enzymes, Biological Control and Commercial Applications. G. E. Harman and C. P. Kubicek, eds. Taylor \& Francis, London.

8. Chung, Y. R., and Hoitink, H. A. J. 1990. Interactions between thermophilic fungi and Trichoderma hamatum in suppression of Rhizoctonia damping-off in a bark compost-amended container medium. Phytopathology 80:73-77.

9. Conrath, U., Beckers, G. J. M., Flors, V., Garcia-Augustin, P., Jakab, G., Mauch, F., Newman, M. A., Pieterse, C. M. J., Poinssot, B., Pozo, M. J., Pugin, A., Schaffrath, U., Ton, J., Wendehenne, D., Zimmerli, L., and Mauch-Mani, B. 2006. Priming: Getting ready for battle. Mol. PlantMicrobe Interact. 19:1062-1071.

10. De Meyer, G., Bigirimana, J., Elad, Y., and Hofte, M. 1998. Induced systemic resistance in Trichoderma harzianum T39 and biocontrol of Botrytis cinerea. Eur. J. Plant Pathol. 104:279-286.

11. Djonovic, S., Pozo, M. J., Dangott, L. J., Howell, C. R., and Kenerley, C. M. 2006. Sm1, a proteinaceous elicitor secreted by the biocontrol fungus Trichoderma virens induces plant defense responses and systemic resistance. Mol. Plant-Microbe Interact. 19:838-853.

12. Garrett, K. A., Madden, L. V., Hughes, G., and Pfender, W. F. 2004. New applications of statistical tools in plant pathology. Phytopathology 94:999-1003.

13. Harman, G. E. 2006. Overview of mechanisms and uses of Trichoderma spp. Phytopathology 96:190-194.

14. Harman, G. E., Howell, C. R., Viterbo, A., Chet, I., and Lorito, M. 2004. Trichoderma species—opportunistic, avirulent plant symbionts. Nat. Rev. Microbiol. 2:43-56.

15. Harman, G. E., Petzoldt, R., Comis, A., and Chen, J. 2004. Interactions between Trichoderma harzianum strain T22 and maize inbred line Mo17 and effects of this interaction on diseases caused by Pythium ultimum and Colletotrichum graminicola. Phytopathology 94:147-153.

16. Hoitink, H. A. J., and Boehm, M. J. 1999. Biocontrol within the context of soil microbial communities: A substrate-dependent phenomenon. Annu. Rev. Phytopathol. 37:427-446.

17. Hoitink, H. A. J., Madden, L. V., and Dorrance, A. E. 2006. Systemic resistance induced by Trichoderma spp.: Interactions between the host, the pathogen, the biocontrol agent, and soil organic matter quality. Phytopathology 96:186-189.

18. Horsfall, J. G., and Barrett, R. W. 1945. An improved grading system for measuring plant diseases. (Abstr.) Phytopathology 35:655.

19. Horst, L. E., Locke, J., Krause, C. R., McMahon, R. W., Madden, L. V., and Hoitink, H. A. J. 2005. Suppression of Botrytis blight of begonia by Trichoderma hamatum 382 in peat and compost-amended potting mixes. Plant Dis. 89:1195-1200.

20. Howell, C. R. 1998. The role of antibiosis in biocontrol. Pages 173-184 in: Trichoderma and Gliocladium. Volume 2. Enzymes, Biological Control and Commercial Applications. G. E. Harman and C. P. Kubicek, eds. Taylor \& Francis, London.

21. Howell. C. R. 2006. Understanding the mechanisms employed by Trichoderma virens to effect biological control of cotton diseases. Phytopathology 96:178-180.

22. Howell, C. R., Hanson, L. E., Stipanovic, R. D., Puckhaber, L. S., and Wheeler, M. H. 2000. Induction of terpenoid synthesis in cotton roots and control of Rhizoctonia solani by seed treatment with Trichoderma virens. Phytopathology 90:248-252.

23. Khan, J., Ooka, J. J., Miller, S. A., Madden, L. V., and Hoitink, H. A. J. 2004. Systemic resistance induced by Trichoderma hamatum 382 in cucumber against Phytophthora crown rot and leaf blight. Plant Dis. $88: 280-286$

24. Krause, M. S., De Ceuster, T. J. J., Tiquia, S. M., Michel, F. C., Jr., Madden, L. V., and Hoitink, H. A. J. 2003. Isolation and characterization of rhizobacteria from compost that suppress the severity of bacterial leaf spot of radish. Phytopathology 93:1292-1300.

25. Lee, S. B., and Taylor, J. W. 1990. Isolation of DNA from mycelia and single spores. Pages 282-287 in: PCR Protocols: A Guide to Methods and Applications. M. A. Innis, D. H. Gelfand, J. T. Sninsky, and T. J. White, eds. Academic Press, San Diego, CA. 
26. Lelliot, R. A., and Stead, D. E. 1987. Methods for the Diagnosis of Bacterial Diseases of Plants. Blackwell Scientific Publications, Ltd., Oxford.

27. Merkouropoulos, G., and Shirsat, A. H. 2003. The unusual Arabidopsis extension gene atExt 1 is expressed throughout plant development and is induced by a variety of biotic and abiotic stresses. Planta 217:356-366.

28. Mills, H. A., and Jones, J. B., Jr. 1996. Page 366 in: Plant Analysis Handbook II: Greenhouse Tomato. MicroMacro Publishing, Inc., Athens, GA.

29. Nuwasir, E. F., Huang, W., Albert, T. J., Singh, J., Nuwaysir, K., Pitas, A., Richmond, T., Gorski, T., Berg, J. P., Ballin, J., McCormick, M., Norton, J., Pollock, T., Sumwalt, T., Butcher, L., Porter, D., Molla, M., Hall, C., Blattner, F., Sussman, M. R., Wallace, R. L., Cerrina, F., and Green, R. D. 2002. Gene expression analysis using oligonucleotide arrays produced by maskless photolithography. Genome Res. 12:1749-1755.

30. Pharand, B., Carisse, O., and Benhamou, N. 2002. Cytological aspects of compost-mediated induced resistance against Fusarium crown and root rot in tomato. Phytopathology 92:424-438.

31. Pieterse, C. M. J., Van Pelt, J. A., Verhagen, B. W. M., Ton, J., van Wees, S. C. M., Leon-Kloosterziel, K. M., and Van Loon, L. C. 2003. Induced systemic resistance by plant growth promoting rhizobacteria. Symbiosis 35:39-54.

32. Puustjarvi, V., and Robertson, R. A. 1975. Physical and chemical properties. Pages 23-28 in: Peat in Horticulture. D. W. Robinson and J. G. D. Lamb, eds. Academic Press, New York.

33. Sahin, F., and Miller, S. A. 1996. Occurrence and identification of a bacterial spot disease of radish in Ohio. Phytopathology 86:S79.

34. Segarra, G., Jauregui, O., Casanova, C., and Trillas, I. 2006. Simultaneous quantitative LC-ESI-MS/MS analyses of salicylic acid and jasmonic acid in crude extracts of Cucumis sativus under biotic stress. Phytochemistry 67:395-401.

35. Shah, D. A., and Madden, L. V. 2004. Nonparametric analysis of ordinal data in designed factorial experiments. Phytopathology 94:33-43.

36. Shanmugam, V. 2005. Role of extracytoplasmic leucine rich repeat proteins in plant defense mechanisms. Microbiol. Res. 160:83-94.

37. Sijam, K., Chang, C. J., and Gitaitis, R. D. 1991. An agar medium for the isolation and identification of Xanthomonas campestris pv. vesicatoria from seed. Phytopathology 81:831-834.

38. Sivasithamparam, K., and Ghisalberti, E. L. 1998. Secondary metabolism in Trichoderma and Gliocladium. Pages 139-192 in: Trichoderma and Gliocladium. Volume 1. Basic Biology, Taxonomy and Genetics. C. P. Kubicek and G. E. Harman, eds. Taylor \& Francis, London.

39. Soresh, M., Yedidia, I., and Chet, I. 2005. Involvement of jasmonic acid/ethylene signaling pathway in the systemic resistance induced in cucumber by Trichoderma asperellum T203. Phytopathology 95:76-84.

40. Wang, Y., Ohara, Y., Nakayashiki, H., Tosa, Y., and Mayama, S. 2005. Microarray analysis of the gene expression profile induced by the endophytic plant growth-promoting rhizobacteria, Pseudomonas fluorescens FPT9601-T5 in Arabidopsis. Mol. Plant-Microbe Interact. 18:385-396.

41. Wei, G., and Shirsat, A. H. 2006. Extensin over expression in Arabidopsis limits pathogen invasiveness. Mol. Plant Pathol. 7:579-592.

42. Woo, S. L., Scala, F., Ruocco, M., and Lorito, M. 2006. The molecular biology of the interactions between Trichoderma spp., pathogenic fungi, and plants. Phytopathology 96:181-185.

43. Yedidia, I., Benhamou, N., and Chet, I. 1999. Induction of defense responses in cucumber plants (Cucumis sativus L.) by the biocontrol agent Trichoderma harzianum. Appl. Environ. Microbiol. 65:1061-1070.

44. Yedidia, I., Benhamou, N., Kapulnik, Y., and Chet, I. 2000. Induction and accumulation of PR proteins activity during early stages of root colonization by the mycoparasite Trichoderma harzianum strain T-203. Plant Physiol. Biochem. 38:863-873.

45. Yedidia, I., Shoresh, M., Kerem, Z., Benhamou, N., Kapulnik, Y., and Chet, I. 2003. Concomitant induction of systemic resistance to Pseudomonas syringae pv. lachrymans in cucumber by Trichoderma asperelleum (T-203) and accumulation of phytoalexins. Appl. Environ. Microbiol. 69:7343-7353.

46. Yedidia, I., Srivastva, A. K., Kapulnik, Y., and Chet, I. 2001. Effect of Trichoderma harzianum on microelement concentrations and increased growth of cucumber plants. Plant Soil 235:235-242.

47. Zhang, W., Han, D. Y., Dick, W. A., Davis, K. R., and Hoitink, H. A. J. 1998. Compost and compost water extract-induced systemic acquired resistance in cucumber and Arabidopsis. Phytopathology 88:450-455. 